\title{
De la fusión a la difusión en el arte de la Cordoba califal: la ampliación de al-Hakam II en la mezquita aljama
}

\author{
Antonio Momplet Míguez \\ Universidad Complutense de Madrid \\ momplet@ghis.ucm.es
}

El arte omeya andalusí es desde el principio resultado de una combinación de influencias, como lo es en general el arte islámico, y la mezquita de Córdoba es testimonio de ello desde su principio. El ejemplo más significativo sería el de diseño más afortunado, el de las arquerías de la sala de oración que es resultado de la fusión de referentes romanos, bizantinos, visigodos y omeyas de Oriente ${ }^{1}$.

En la época del Califato Córdoba era un verdadero mosaico de gentes, de distintos orígenes, religiones y formas de hablar ${ }^{2}$, y la mezquita sigue siendo testimonio de ello cuando se llega a la espléndida ampliación de al-Hakam II. Como muestra de ello planteo en este estudio una cierta revisión de la secuencia constructiva del oratorio, de los posibles orígenes que tuvieron algunas de sus soluciones arquitectónicas más interesantes y las razones que pudieron provocar ciertas rarezas de su construcción.

Aunque se ha dicho que "pocos edificios de la Edad Media cuentan con fuentes tan numerosas, ricas y precisas para la historia de su construcción" " 3 , la realidad es que la fiabilidad de estas fuentes documentales es muy discutible, especialmente cuando se trata de algunas cuestiones específicas referidas a la ampliación de al-Hakam II, donde se encuentran claras contradicciones. De hecho, una parte sustancial de las referencias concretas a la cronología y a la progresión de las obras proceden de una sola fuente, el Al-Bayan al-Mughrib de Ibn 'Idari escrita a principios del siglo XIV", e incluso este mismo texto cae en contradicciones. En la siguiente secuencia, resumen ordenado cronológicamente de todos los datos concretos que tenemos acerca de la construcción de esta parte de la sala de oración, pueden advertirse las lagunas y contradicciones aludidas:

1 A. MOMPLET, El arte hispanomusulmán, Madrid, 2004-2008, pp. 31-34.

2 C. SÁNCHEZ ALBORNOZ, La España musulmana, Madrid, 1946, t. I, pp. 355 y 434.

3 M. NIETO CUMPLIDO, La Catedral de Córdoba, Córdoba, 1998, p. 30.

${ }^{4}$ La obra de IBN 'IDARI al-MARRAKUSI Al-Bayan al-Mughrib pasa por ser la mayor recopilación de noticias históricas sobre la mezquita de Córdoba. Buena parte de sus datos parecen basarse en la obra $\mathrm{Al}$ Muqtabis del historiador cordobés IBN HAYYAN (987/988-1075/1076). 
- 961, 16 octubre: visto bueno a la ampliación y autorización del califa para conseguir el material en el zoco de piedra (Ibn 'Idari - principios s. XIV).

- 962, julio: se comenzó la edificación de la mezquita (Ibn 'Idari - principios s. XIVbasado, según el autor, en un autógrafo del propio califa).

- 963: el cadi Mundir ibn Sa’id marchó hacia la mezquita para estudiar los trabajos del ensanche a realizar [...] (Ibn 'Idari - principios s. XIV).

- 965, junio: Se acabó la cúpula del mihrab (Ibn 'Idari - principios s. XIV).

- 965, junio: se comenzaron a hacer las incrustaciones de mosaico de este edificio (Ibn 'Idari - principios s. XIV').

- 965, octubre: al-Hakam II fue desde Madīnat al-Zahrā' a la mezquita, examinó la ampliación, y ordenó "extraer de sus cimientos" las cuatro columnas situadas en las jambas del antiguo mihrab, las cuales no tenían parecido alguno a otras, dejándolas a un lado para volverlas a colocar en el nuevo mihrab cuando el avance de los trabajos lo permitiese (Ibn 'Idari - principios s. $\mathrm{XIV}^{6}$ ).

- 965, diciembre: al-Hakam II mandó a Ya'far ibn 'Abd al-Rahmān fijar estas dos impostas en lo que fundó [...] ( inscripción en impostas arco mihrab ${ }^{7}$ ).

- 965, diciembre: en lo que erigió de este mihrab, revestirlo de mármol [...] Y se terminó aquello bajo la dirección [...] en [...] (inscripción en remate del zócalo interior del $\operatorname{mihrab}^{8}$ ).

- 965-966: se terminó la construcción del mimbar y se instaló en la macsura (Dikr bilad al-Andalus - s. XIV ${ }^{9}$ ).

- 966, enero: ordenó poner el antiguo mimbar al lado del mihrab y puso la antigua macsura [...] (Ibn 'Idari - principios s. XIV).

- 966, julio: se concluyó una nueva macsura de madera en la quibla (Ibn 'Idari - principios s. XIV).

- 966: se terminó la edificación de la mezquita (Ibn 'Idari - principios s. XIV- basado, según el autor, en un autógrafo del propio califa).

- 967, enero: empieza a fluir el agua para los depósitos y espacios para abluciones de la mezquita (Ibn 'Idari - principios s. XIV).

- 968-969: se termina una construcción ordenada por al-Hakam II (inscripción conmemorativa en una placa de mármol descontextualizada y conservada en la mezquita). Hipótesis que se refiera a la obra del lucernario ${ }^{10}$.

5 Abad no cree que este revestimiento se acabase hasta 968-969, vid. C. ABAD CASTRO "El oratorio de al-Hakam II en la mezquita de Córdoba”, Anuario del Departamento de Historia y Teoría del Arte, 21 (2009), p. 20 .

6 Ibidem, p. 12. Se indica que la traducción literal es "hasta que las pusieron en el muro del mihrab hasta que terminaron de colocarlas y terminarlas correctamente".

7 Ibídem y M. NIETO CUMPLIDO, op. cit., 1998.

8 Ibidem.

9 F. N. VELÁZQUEZ BASANTA, "Un texto de Yusuf III sobre la génesis de la Ihata que nos da la clave para conocer al autor del Dikr bilad al-Andalus", Miscelánea de Estudios Árabes y Hebraicos, Sección ÁrabeIslam, 56 (2007), pp. 225-243: en este estudio se identifica al autor como Abu 'Abd Allah Muhammad Ibn Iuzayy, literato y poeta granadino del siglo XIV.

10 C. ABAD CASTRO, op. cit., 2009, p. 16. 
Entre 970 (fecha muerte Ya'far ${ }^{11}$ ) y 973 (muerte jefe de la surta Muhammad b. Tamlij ${ }^{12}$ ): se conmemora la realización de la puerta del sabat (inscripción alfiz interior de la puerta).

- 976: se abrió una puerta al lado izquierdo de la del sabat para albergar el nuevo mimbar.

- 975, septiembre-976, agosto: se concluyó la ampliación de la mezquita ${ }^{13}$ y se describe el nuevo mimbar (Ibn 'Idari - principios s. XIV).

Por consiguiente, cabe deducir que las referencias documentales acerca de la cronología de la construcción del oratorio de al-Hakam II son limitadas y en ocasiones contradictorias. Por lo tanto, no se deben aceptar como indiscutibles y, por el contrario, cabe intentar determinar la secuencia de la edificación poniéndolas en relación con una interpretación lógica de sus fases y con las evidencias materiales conserva$\operatorname{das}^{14}$.

La hipótesis previa más lógica de cómo se construyó el oratorio respondería a la siguiente secuencia:

1. Relleno y nivelación del terreno en función del acusadísimo declive del mismo en dirección al río Guadalquivir, construyéndose el grueso muro en el extremo sur que ejercería de cimentación y contrafuerte de toda la ampliación y de soporte de la zona de la quibla.

2. Construcción de los muros de la quibla desdoblada del oratorio.

3. Elevación de los muros del perímetro exterior en los lados occidental y oriental incluyendo la situación de las puertas.

4. Edificación de las arquerías de las naves.

En relación con el mantenimiento del uso de la mezquita anterior, lo más lógico es que el mihrab de 'Abd al-Rahmān II existiera, al menos, hasta octubre de 965, cuando se retiran sus columnas para instalarlas en el nuevo mihrab y que, hasta entonces, la oración se siguiese haciendo hacia la quibla y mihrab antiguos ${ }^{15}$. Por consiguiente hasta ese momento, al menos, estos elementos se mantendrían y el muro de quibla no estaría aún horadado.

11 M. NIETO CUMPLIDO, op. cit., 1998, p. 188: se cita al hayib de forma que indica que ya había fallecido, cosa que sucedió en 970 .

12 C. ABAD CASTRO, op.cit., 2009, p. 21.

13 E. FAGNAN en su traducción del texto de IBN 'IDARI, Histoire de l'Afrique et de l'Espagne intitulé al-Bayano 'l-Mogrib, Argel, 1904, señala que esta fecha para la terminación se contradice con el mismo texto y que pudiera tratarse de un error del copista.

14 C. ABAD CASTRO, op. cit., 2009, pp. 9-30: considera que el proyecto de al-Hakam II se materializó a lo largo de prácticamente todo su reinado, en varias etapas constructivas continuas.

15 Ibídem, p. 12. 


\section{EL PROBLEMA DE LA ARQUERÍA TRANSVERSAL}

A pesar de haberse insistido en esta idea repetidamente, no existe en la ampliación de al-Hakam II una nave de quibla al modo de otras mezquitas anteriores como la de Abu Dulaf en Samarra y, muy especialmente, de la mezquita de Kairuan construida en el siglo IX, la cual empleamos sistemáticamente como referente comparativo para la aljama cordobesa. Ello es lógico y aceptable en muchos aspectos, pero no en la de la supuesta nave de quibla del oratorio de al-Hakam II, pues entre ellas se dan diferencias sustanciales:

1. La continuidad de las arquerías, que penetran el espacio diferenciado próximo a la quibla en dos tramos (fig. 1).

2. La no existencia de una crujía paralela a la quibla como sucede en los otros ejemplos. En Córdoba las naves y sus correspondientes cubiertas mantienen su continuidad hasta la misma quibla ${ }^{16}$.

Protagonista fundamental de este equívoco es la arquería transversal que es continuidad de la frontal de la macsura hacia el este y el oeste. Esta arquería ha sido esencial a la hora de interpretar esos dos últimos tramos de las naves como un espacio asociado paralelamente a la quibla. Sin embargo, en sus dos extremos remata de manera absolutamente absurda, desde la lógica arquitectónica, sobre las correspondientes puertas de los muros laterales. En ambos casos, los últimos arcos de la misma van a caer sobre dichas puertas y totalmente descentrados (fig. 2). La única explicación posible a este espectacular desajuste constructivo es que la susodicha arquería transversal no estaba proyectada inicialmente y se construye cuando ya lo está el perímetro de la ampliación con sus correspondientes puertas. Esta tuvo que ser la razón de semejante anomalía.

16 G. RUIZ CABRERO, Dibujos de la Catedral de Córdoba. Visiones de la Mezquita, Córdoba, 2009, pp. 30 y 33: “...la nave central rematada en T por una nave transversal que prolonga hasta los muros laterales el espacio cubierto en su centro por las cúpulas de la macsura. Esta nave es una crujía transversal con la cubierta a dos aguas, perpendicular a las once que vienen desde el patio. Sobre esta estructura de gran transparencia (la arquería transversal) discurre un elemento constructivo fundamental: un canal transversal que evacuaba más de la mitad de las aguas recogidas en la cubierta, construida por Alaquén II, vertiéndolas a oriente y occidente". Creo que estas afirmaciones no son del todo correctas. Por lo que puede deducirse en su situación actual, parece que las cubiertas de las ocho naves laterales (cuatro a cada lado) se prolongaban hasta la quibla interior. La que sí es una crujía transversal, con su propia cubierta perpendicular a las de las naves, es la del sabat, y al otro lado la del tesoro. La apariencia actual del exterior de las naves 1, 10 y 11 parece confirmarlo y, desde luego, se ratifica absolutamente en el interior de la nave 1, la extrema occidental. Sí es cierto que existe una canalización por encima de la arquería transversal que se interrumpe sin cruzar las naves extremas. En esos puntos conecta con las canalizaciones sobre las arquerías correspondientes perpendiculares a la quibla, y el desagüe se hace posible a través de estas y su conexión con la que corre por encima del muro de la quibla interior, antes de la crujía del sabat/tesoro, para desaguar, lógicamente, por el contrafuerte correspondiente, como en el resto de la mezquita. Vuelve a ser, en mi opinión, resultado de una reforma, bien cuando se construye la arquería transversal, o cuando se reforman esos tramos finales construyendo las capillas correspondientes de la catedral. Si se observa el exterior de la fachada correspondiente en el lado oeste, se comprueba que es imposible que haya habido un canal de desagüe que corriese por encima de la arquería transversal y desembocase en este lado. 


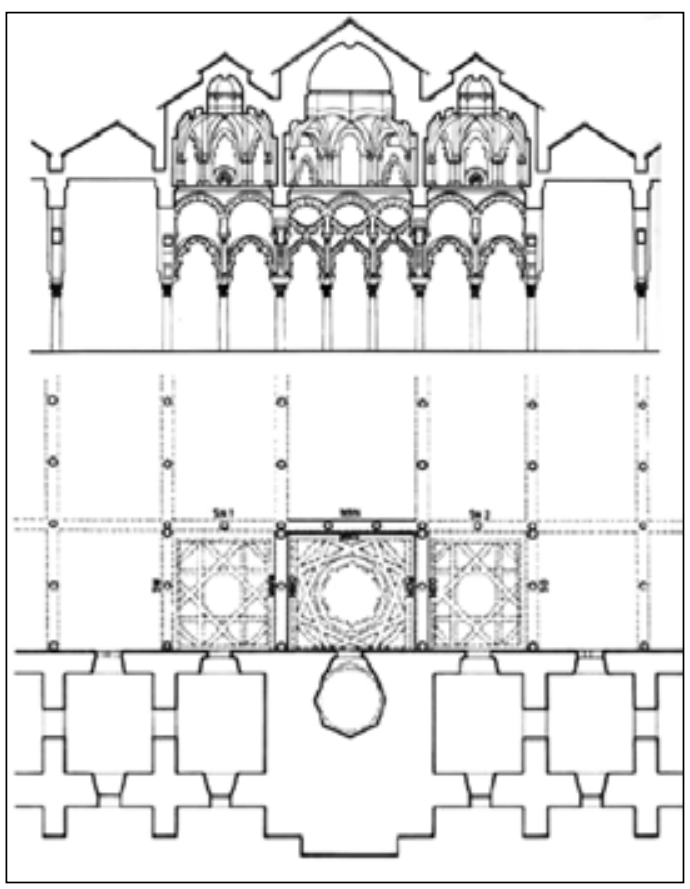

Fig. 1. Mezquita de Córdoba. Ampliación de Al-Hakam II: planta y alzado de la zona del mihrab y la macsura.

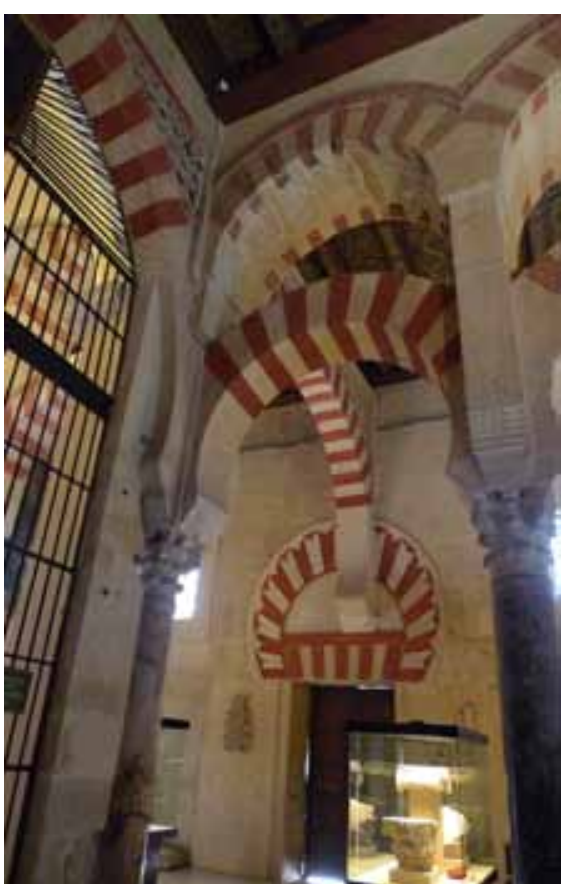

Fig. 2. Extremo occidental de la arquería transversal sobre la puerta de San Ildefonso.

¿Y, cuál fue la causa? La única explicación razonable es que hubiese un cambio de proyecto cuando ya el perímetro y la situación de las puertas estaban definidos, y que tuvo que estar relacionado con el apeo de las bóvedas de la macsura. Es decir, la construcción de las tres bóvedas con su elevado peso hizo necesario desarrollar una serie de soluciones de contrarresto. Entre ellas se debió entender como imprescindible descargar lateralmente los empujes de la parte frontal de la macsura hasta llevarlos a los muros de las fachadas oriental y occidental de la ampliación. Esa fue la función esencial de la arquería transversal que, partiendo de la macsura, va apoyándose sucesivamente en los correspondientes soportes de las arquerías de las naves, hasta acabar integrándose en los muros perimetrales encajándose de manera forzada sobre las puertas ${ }^{17}$.

Es curioso observar cómo en las plantas de esta ampliación realizadas por dos de los más destacados historiadores de nuestra arquitectura, Leopoldo Torres

17 Ibídem, p. 31: el autor, arquitecto restaurador de la catedral de Córdoba, afirma que "Estas cúpulas descansan sobre el muro de la quibla, sobre las cuatro arquerías que definen las tres naves y sobre una arquería transversal paralela a la quibla, que nos interesa especialmente y que hemos llamado "traviesa". ...su finalidad es garantizar, arriostrando las naves longitudinales, que las tres cúpulas de gran peso no puedan torsionar sobre las columnas que las sostienen". 
Balbás y Fernando Chueca, se refleja la macsura pero no la continuidad de su frente en la arquería transversal. Parecería ser una sugerencia visual de algo que ninguno de los dos puso por escrito: que efectivamente esa prolongación de arcos no se correspondía con el proyecto original o, incluso, que la consideraban un "pegote" arquitectónico.

Existen otros aspectos en la construcción de la ampliación que colaboran a reforzar la hipótesis de una reforma del proyecto centrado en la construcción de las bóvedas. Se comprueba que existe una manifiesta diferencia de altura entre los soportes de la macsura y los del resto del oratorio. La altura de las columnas de toda la macsura, con sus correspondientes capiteles, es menor que la del resto de las columnas de la zona más próxima del oratorio. Esta diferencia provoca que los últimos arcos de las tres naves centrales inmediatamente anteriores a la macsura sean de herradura irregular. Esta diferencia de alturas parece mantenerse, aunque en menor medida, en las columnas inmediatamente siguientes de la arquería transversal, es decir aquellas donde apoyan los arcos apuntados. Todo parece ser parte de los ajustes que se hicieron necesarios a la hora de incorporar los abovedamientos de la macsura y adaptarlos a las estructuras preexistentes. Sucede lo mismo en las columnas del lucernario respecto de las de la nave central. Asimismo, se doblaron las columnas del frente de la macsura, lo que hace que el primer intercolumnio del lateral sea más estrecho ${ }^{18}$. En diferentes lugares de la macsura y de la arquería transversal pueden también apreciarse en los soportes algunos desajustes e irregularidades que parecen derivar de la misma necesidad de adaptar la nueva estructura.

Los principales autores que han realizado aproximaciones al uso y significado simbólico relacionado con las bóvedas de la macsura y, especialmente con la central, coinciden en interpretarlas como la exaltación del espacio reservado al califa y el simbolismo de su poder absoluto derivado del trono divino ${ }^{19}$. En mi opinión, sería la consecuencia material más evidente de que el significado simbólico referido al califa y su poder fueron el origen de la reforma del plan original de esta parte del oratorio de al-Hakam $\mathrm{II}^{20}$. El nacimiento de sus primeros hijos varones, el malogrado 'Abd al-Rahmān e Hixem, precisamente en los años 962 y 965, creo que está directamente conectado con la decisión de sublimar el espacio frente al mihrab, como testimonio de la certeza en la continuidad dinástica del califa por

18 C. ABAD CASTRO, op. cit., 2009, p. 19: señala que para trazar las arquerías perpendiculares a la quibla que delimitan los tres tramos de la macsura fue necesario introducir columnas emparejadas en los intercolumnios de la cara norte de la misma. De ahí que el primer intercolumnio resulte algo mas estrecho. Es otra irregularidad resultante de la necesidad de adaptar el trazado del espacio a la nueva estructura rematada por las cúpulas.

19 S. CALVO CAPILlA, "La ampliación califal de la mezquita de Córdoba: mensajes, formas y funciones", Goya: Revista de Arte, 323 (2008), p. 98; M. MORENO ALCALDE, "El paraíso desde la tierra. Manifestaciones en la arquitectura hispanomusulmana", Anales de Historia del Arte, 15 (2005), pp. 72-74.

20 S. CALVO CAPILLA, op. cit., 2008, p. 90: la macsura es un espacio áulico complementario de los salones de los alcázares de al-Zahrā’ y de Córdoba; C. ABAD CASTRO, op. cit., 2009, p. 14: la macsura se trataba de un espacio acotado, ideado por el monarca tomando como modelo, muy probablemente, las tres naves del salón de recepción de Madīnat al-Zahrā', cuyas proporciones en anchura resultan idénticas, como lo son también las de las tres naves centrales de la mezquita de la ciudad palatina. 
vía directa. Además, es importante recordar que será en este lugar donde se celebrará la ceremonia de proclamación de Hixem como heredero, hecho igualmente vinculado a la construcción del nuevo mimbar ${ }^{21}$.

\section{LA CUESTIÓN DEL LUCERNARIO}

Aunque sea un espacio diferente al de la macsura, es evidente la conexión entre el lucernario, a la entrada de la ampliación, y el desarrollo arquitectónico simbólico del programa edificatorio.

$\mathrm{Si}$, efectivamente, hasta octubre de 965, cuando se retiran las columnas del $\mathrm{mi}$ hrab de 'Abd al-Rahmān II para instalarlas en el nuevo y, hasta entonces, la quibla y el mihrab antiguos habían seguido existiendo, esta circunstancia sería un serio obstáculo para pensar que el lucernario estuviese ya construido ${ }^{22}$. Si, por lo tanto, su construcción, como es lógico, está relacionada con la de la macsura y sus bóvedas, quedaría por determinar si se construyó simultáneamente, antes, o después. La necesidad de conservar, en relación con la actividad de la mezquita, el mihrab de 'Abd al-Rahmān II hasta el último momento posible, sugiere que la obra del lucernario, aunque se hubiese podido iniciar al tiempo que la de la macsura, debió de completarse posteriormente $\mathrm{o}$, cuando menos, nunca antes ${ }^{23}$. Aunque forman parte de una misma idea arquitectónica y decorativa, las diferencias estructurales del espacio arquitectónico y de la bóveda misma, con respecto a los de la macsura tienden a sugerir dos momentos diferentes. Si, efectivamente, es posterior o consecuencia de lo hecho en la macsura, pudo construirse tratando de resolver, y no repetir, algunos de los problemas que aquella había generado. Esta posibilidad podría ponerse en relación con la interesante hipótesis planteada hace unos años por el profesor Ruiz Souza ${ }^{24}$. $\mathrm{Su}$ teoría de la "fachada luminosa" defiende la existencia de dos espacios abovedados flanqueando el lucernario, a imagen y semejanza de lo realizado en la macsura. La extrañeza que a él mismo le producía el hecho de que las bóvedas laterales se elevasen por encima de la central podría explicarse como resultado de intentar una solución de contrarresto diferente que evitase lo sucedido frente a la quibla.

21 M. FIERRO, "The Mobile Mimbar in Cordoba. How the Ummayads of al-Andalus Claimed the Inheritance of the Prophet", Jerusalem Studies in Arabic and Islam, 33 (2007), pp. 149-168; S. CALVO CAPILLA, op. cit., 2008, p. 99.

22 C. ABAD CASTRO, op. cit.,2009, pp. 12 y 16: según reza una inscripción conmemorativa en una placa de mármol descontextualizada y conservada en la mezquita en 968-969 se termina una construcción ordenada por al-Hakam II. La autora sostiene la hipótesis de que se refiera a la obra del lucernario. Otros autores difieren y consideran lo mas probable que la citada lápida marmórea proceda de Madīnat al-Zahrā'.

23 La reflexión sobre los condicionantes de la secuencia constructiva de esta ampliación me ha llevado a rectificar mi anterior idea sobre este aspecto: A. MOMPLET, “¿Quién construyó la mezquita de Córdoba? De las evidencias a las hipótesis", Goya: Revista de Arte, 294 (2003), p. 155.

24 J. C. RUIZ SOUZA, "La fachada luminosa de de al-Hakam II en la mezquita de Córdoba", Madrider Mitteilungen, 42 (2001), pp. 432-445. 


\section{HIPÓTESIS SOBRE LA SECUENCIA CONSTRUCTIVA DEL ORATORIO DE AL-HAKAM II}

1. Planificación final. Relleno del terreno hasta crear una plataforma nivelada a ras de suelo de la mezquita preexistente, incluyendo el gran muro de contención en el extremo sur. Se mantiene cerrada la quibla y mihrab de 'Abd al-Rahmān II (a partir de octubre de 961).

2. Construcción de los muros perimetrales del nuevo oratorio incluyendo la posición de las puertas. Incluye la elevación de la nueva quibla desdoblada (año 962) (fig. 3).

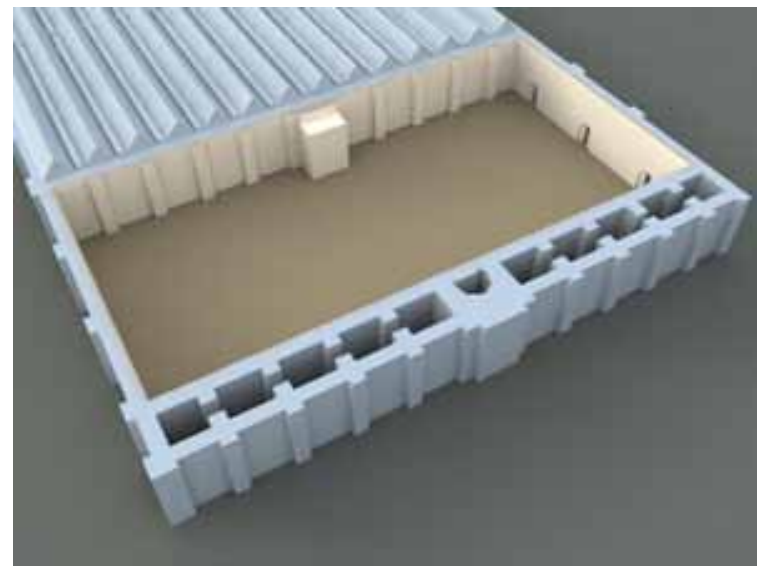

Fig. 3. Ampliación de Al-Hakam II: primeras fases de su construcción.

3. Construcción de las arquerías de las naves. En un principio sin proyectar un remate diferenciado frente al mihrab y sin la idea de planta en T (años 962-963) (fig. 4).

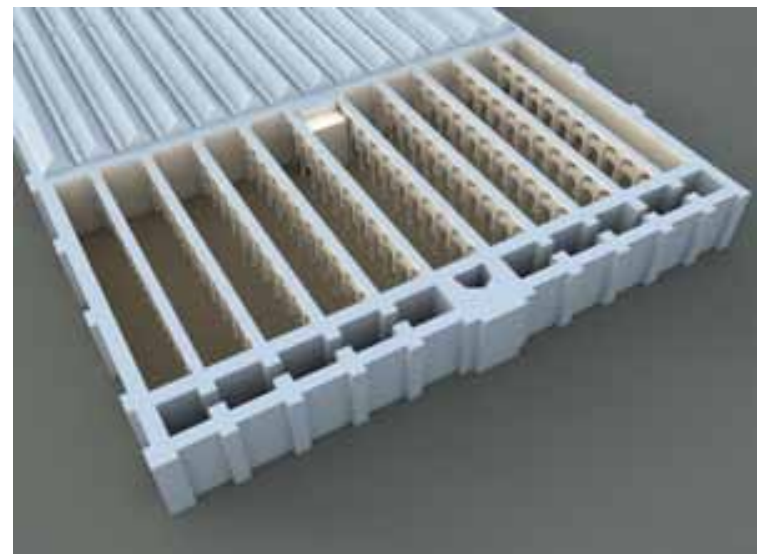

Fig. 4. Ampliación de Al-Hakam II: incorporación de las arquerías de las naves. 
4. Reforma del proyecto inicial. Se decide la construcción de un triple espacio abovedado frente al mihrab, creando una macsura arquitectónica (fig. 5). Como consecuencia de ello, y para controlar sus empujes, se construye la arquería transversal (años 964-966) $)^{25}$ (fig. 6).

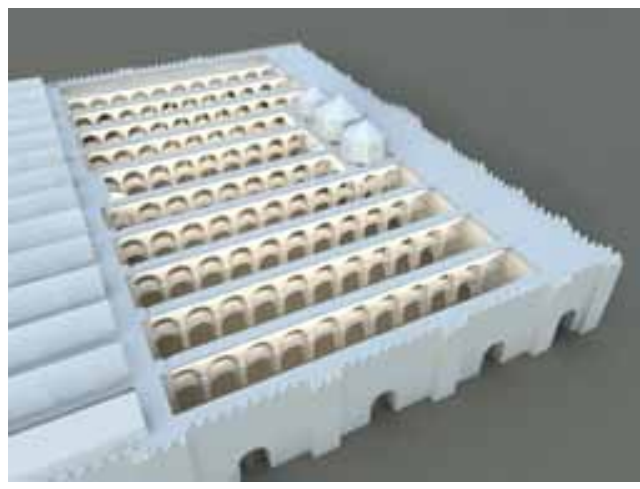

Fig. 5. Ampliación de Al-Hakam II: construcción de las bóvedas de la macsura.

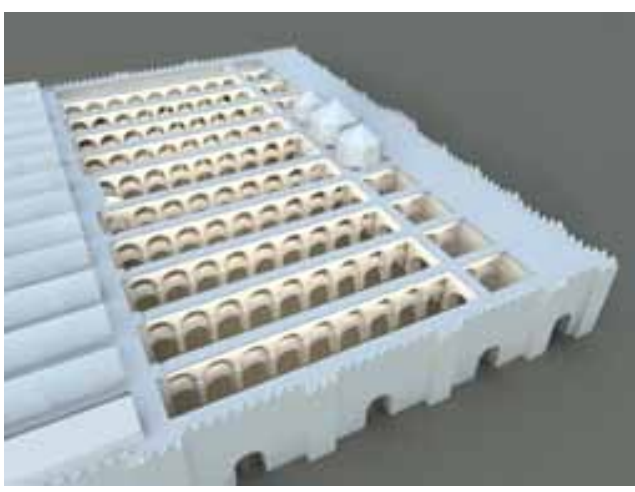

Fig. 6. Ampliación de Al-Hakam II: adición de la arquería transversal.

5. Se construye el lucernario (fig. 7) y tal vez sus espacios abovedados adyacentes. Se abre el muro de quibla anterior, construyéndose la arquería-fachada de entrada a la ampliación de al-Hakam II y desaparece definitivamente el mihrab antiguo. El nuevo oratorio esta completo y con plena funcionalidad (años 967-970).

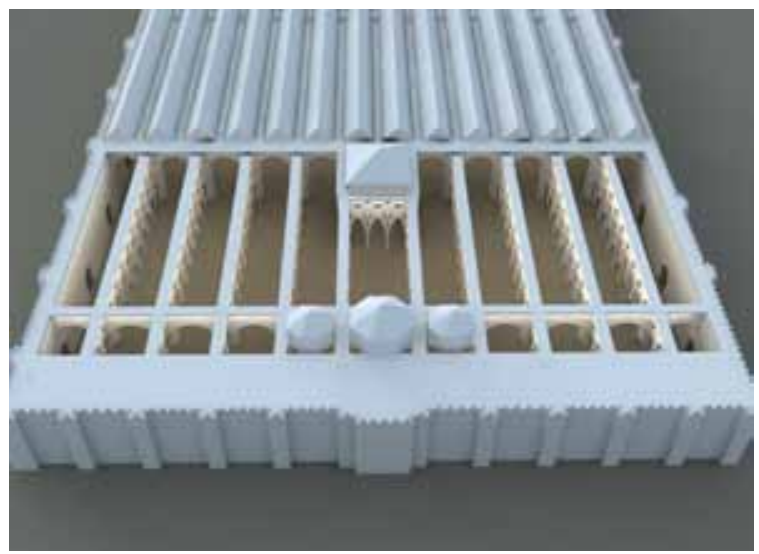

Fig. 7. Ampliación de Al-Hakam II: incorporación del Lucernario.

25 C. ABAD CASTRO, op. cit., 2009, p. 16: en su opinión, es a mediados de 966 cuando se inicia una segunda etapa en la que se elevarán los grandes espacios cupulados. Insiste en la extrañeza que provoca que pasaran seis años entre la conclusión del mihrab (965) hasta que se finaliza la colocación de los mosaicos (971-973). Cree que entre esas fechas se realizaría el lucernario y sus tramos adyacentes e, incluso, la macsura definitiva delante del mihrab. 


\section{FILIACIÓN DE LOS ARTÍFICES IMPLICADOS EN ESTE CAMBIO DE PROYECTO}

Creo que la respuesta a quién o quiénes intervienen en este cambio de proyecto y cuál sería su filiación más probable ha de estar relacionada con las novedosas bóvedas de crucería califal, y que su posible origen está relacionado con Bizancio, tal y como he venido defendiendo desde hace tiempo ${ }^{26}$.

Es bien sabido que las relaciones entre al-Andalus y el Imperio Bizantino durante el siglo X fueron estrechas en el ámbito de lo político. En realidad, durante el gobierno de los emperadores Constantino VII (913-959), Romano II (959-963), Nicéforo II Focas (963-969) y Juan I Tzimisces (969-976) los intercambios entre Bizancio y Córdoba dieron lugar a muchas más embajadas que las dos o tres que habitualmente se consideran ${ }^{27}$. Pero, además, existen referencias artísticas relacionadas con lo bizantino presentes en la Córdoba califal. A Madīnat al-Zahrā’, además de materiales y obras de arte procedentes de Bizancio, llegaron arquitectos y maestros de obras procedentes de Bagdad y Constantinopla que fueron dirigidos por el arquitecto y geómetra Maslama ibn 'Abd Allah ${ }^{28}$. También en el Alcázar de Córdoba, cuando 'Abd al-Rahmān III construyó su Dar al-Rawda, trabajaron arquitectos y maestros de obras venidos del Oriente islámico y de Constantinopla ${ }^{29}$. Por otra parte, en el campo de la eboraria sabemos que los creadores de marfiles califales acudieron a modelos bizantinos como inspiración ${ }^{30}$. Y, por supuesto, resulta trascendental la noticia del envío de un musivara por el emperador bizantino, Nicéforo Focas, con toda probabilidad a petición del califa cordobés para llevar a cabo la decoración de mosaicos en la macsura de la mezquita ${ }^{31}$. De hecho, ha de entenderse, en mi opinión, mucho más

26 A. MOMPLET, op. cit., 2003, pp. 153 y ss ; R. ROMERO Y BARROS, Córdoba Monumental y Artística, Córdoba, 1884: resulta tan curioso como significativo que el autor entonces ya las defina como cúpulas "neo-griegas".

27 J. SIGNES CODONER, "Bizancio y Al-Andalus en los siglos IX y X”, I. PÉREZ MARTÍN y P. BÁDENAS DE LA PEÑA (eds.), Bizancio y la Península Ibérica. De la Antigüedad Tardia a la Edad Media, Madrid, 2004; J. VERNET, "Natural and Technical Sciences in al-Andalus", S.K. JAYYUSI (ed.), The Legacy of al-Andalus, Leiden, 1992, pp. 937-951; C. MANGO, The Art of the Byzantine Empire, Toronto, 1986, p. 209. Entre otras referencias, se sabe de embajadores bizantinos que vienen entre 947 y 949 fueron hospedados en la almunia al-Naura, palacio del príncipe heredero al-Hakam. También se menciona una carta del emperador bizantino a al-Hakam II, al parecer acompañando un libro de filosofía. Constantino VII le había enviado un ejemplar ilustrado del Dioscórides a 'Abd al-Rahmān III y este le había solicitado después un traductor del griego, y el emperador le envió a un monje llamado Nicolás (951-952) que permaneció en Córdoba hasta la época del califa al-Hakem II. Liutprando (c. 920-972), obispo de Cremona y diplomático, refiere en su Antapodosis que su audiencia ante el emperador Constantino VII en el año 949 la compartió con enviados "españoles".

28 L. TORRES BALBÁS, “Arte hispanomusulmán hasta la caída del califato de Córdoba”, R. MENÉNDEZ PIDAL (dir.), Historia de España, tomo V, Madrid, 1965, pp. 432-434, y R. CÓMEZ, Los constructores de la España medieval, Sevilla, 2001, p. 32: estos autores recogen el dato de IBN JALDÚN en Kitab al-Ibar, y AL-MAQQARĪ en Nafh al-Tib.

29 E. LÉVI PROVENÇAL, L'Espagne musulmane au Xe siecle, Paris, 1932, p. 224. Es también un dato procedente de IBN JALDÚN y reproducido por AL-MAQQARI.

30 N. SILVA, Los marfiles hispanomusulmanes, vol. I, Tesis doctoral inédita, Universidad Complutense de Madrid, 2011, pp. 70-76.

31 IBN 'IDARI, Kitab al-Bayan al-Mughrib, p. 392. 
allá de su evidente trascendencia en este importante apartado decorativo. Supone la ratificación de la presencia y actividad de artífices de ese origen en las obras de la ampliación de al-Hakam II. La originalidad y atractivo de ese tipo de técnica decorativa en la Córdoba califal explica que sea a la que, prioritariamente, alude el historiador. Sin embargo, parece lógico deducir que es solo una parte de lo que sería una contribución mucho más amplia de mano de obra y soluciones artísticas del mismo origen. El propio Henri Terrasse señaló en su momento esta misma idea ${ }^{32}$.

Además existen aspectos de la formulación y técnica constructiva de las bóvedas de crucería califal de esta ampliación que directamente las vinculan a la arquitectura bizantina, especialmente el empleo de vigas de madera. Como se demostró en primer lugar con la bóveda central de la macsura (fig. 8) y posteriormente con las restantes, las cúpulas centrales de las mismas apoyan sobre gruesas vigas de madera situadas sobre los nervios (fig. 9) y que, por consiguiente, definen los mismos diseños de estrella (fig. 10). Se da en las tres bóvedas de la macsura y existía también en la del lucernario, donde fueron eliminadas en el siglo XV al desmontar la cubierta ${ }^{33}$. También se emplearon vigas de madera en la mezquita, invisibles insertadas en los muros, en la construcción del alminar ${ }^{34}$. Se trata de una técnica específicamente bizantina, prácticamente desconocida en la Península Ibérica y en la arquitectura andalusí, que consta que se empleaba, no solo en la construcción de muros sino, concretamente, en la de arcos, bóvedas y cúpulas ${ }^{35}$.

Cabe mencionar aquí como una posible secuela de este empleo de madera inserta en fábricas pétreas el caso de la torre de la iglesia de San Millán de Segovia, obra anterior al edificio románico, generalmente asociada a una incierta tradición arquitectónica mozárabe ${ }^{36}$.

Además, existe una íntima relación con las bóvedas y cúpulas de gallones que, en la mayoría de las bóvedas califales, aparecen asociadas con un evidente protagonis-

32 H. TERRASSE, L'art hispano-mauresque des origines au XIII siècle, Paris, 1932, pp. 116-125: bajo el título "La lección de Bizancio" dedica todo el epígrafe a la influencia bizantina en la mezquita de Córdoba, y en relación con este punto escribe, p. 117: “... los textos señalan la venida de Bizancio de mosaístas; pero existen en la ampliación de al-Hakam otras influencias bizantinas tan evidentes que uno está tentado de preguntarse si los historiadores no han reducido voluntariamente el mosaico de huellas del arte cristiano".

33 P. MARFIL RUIZ, "Estudio de las linternas y el extradós de las cúpulas de la Maqsura de la Catedral de Córdoba, antigua mezquita Aljama", Arqueología de la Arquitectura, 3 (2004), pp. 99-105.

34 F. HERNÁNDEZ GIMÉNEZ, El alminar de 'Abd al-Rahman III en la mezquita mayor de Córdoba. Génesis y repercusión, Granada, 1975, pp. 48-50. En este estudio señala el uso de "encadenados de vigas de madera" en el alminar, algunos de los cuales siguen siendo visibles en la actualidad.

35 R. OUSTERHAUT, Master Builders of Byzantium, Princeton, 1999, pp. 210-216: "Refuerzos de madera en arcos y bóvedas", p. 211: "El sistema de encadenados de madera, iniciado en los muros, continúa al nivel de los abovedamientos, donde se hace visible en forma de vigas unidas que se extienden por los arranques de arcos y bóvedas de cañón"; p. 214: "Las cúpulas bizantinas se elevaban normalmente sobre tambores con ventanas donde se empleaban refuerzos de madera. Además de vigas encadenadas en los puntos de arranque, encadenados de madera formando arcos de tensión se construyeron a varios niveles prácticamente en todas las cúpulas bizantinas" [traducción del autor]. En numerosos estudios específicos sobre la arquitectura bizantina se insiste en este aspecto, entre ellos: A. CHOISY, L'Art de batir chez les Byzantynes, Paris, 1883, pp. 121-122; Ibidem, Histoire de l'architecture, vol. 2, Paris, 1954, p. 11; R. J. MAINSTONE, Hagia Sophia. Architecture, Structure and Liturgy of Justinian's Great Church, Londres, 1988, pp. 70-71.

36 J. A. RUÍZ HERNANDO y J. A. RODRÍGUEZ MONTAÑ́́S (coords.), Enciclopedia del Románico en Castilla y León. vol. III. Segovia, Aguilar de Campoo, 2007, p. 1458. 


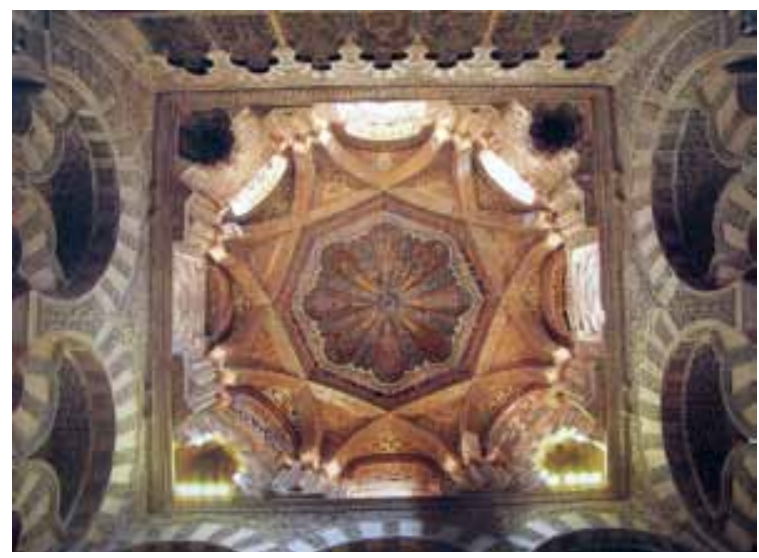

Fig. 8. Bóveda central de la macsura frente al mihrab.

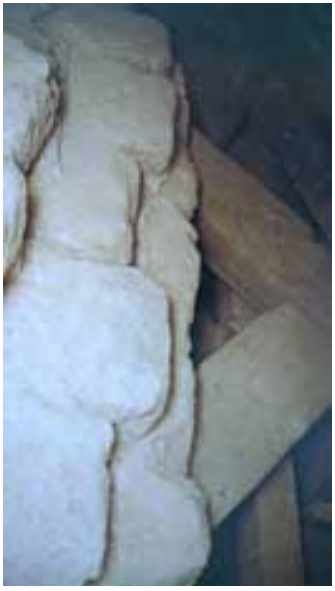

Fig. 9. Bóveda central de la macsura: trasdós de su cúpula central apoyada sobre vigas de madera.

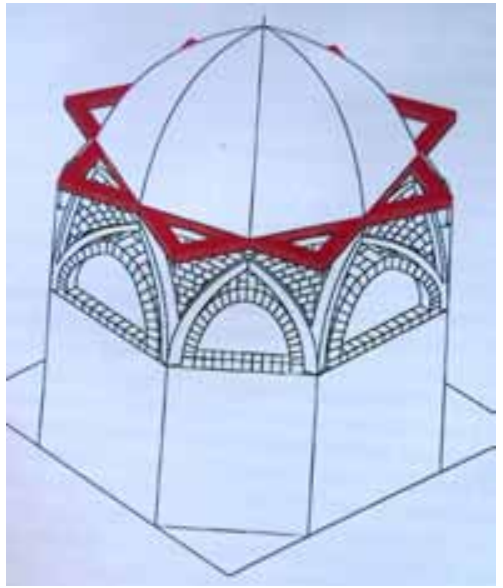

Fig. 10. Bóveda central de la macsura: disposición de las vigas de madera bajo su cúpula.

mo. El inequívoco origen bizantino de las cubiertas gallonadas es, por lo tanto, también un argumento de peso en defensa de estas conexiones, que tal vez se produjeron a través de ejemplos intermedios como las bóvedas tunecinas del siglo IX. Asimismo, se ha mencionado que el diseño geométrico de las bóvedas en cuestión es igualmente una característica común con la arquitectura bizantina, como en el caso del esquema en planta de la Cúpula de la Roca ${ }^{37}$, aunque en mi opinión resulte una referencia exce-

37 A. PAPADOPOULO, El Islam y el arte musulmán, Barcelona, 1977, pp. 243-249. 
sivamente genérica. El posible conflicto respecto a la diferencia entre los materiales utilizados en la construcción de las cúpulas bizantinas, generalmente de ladrillo y materiales ligeros, y las bóvedas cordobesas se resuelve al considerar algunos de los territorios en los que era habitual la arquitectura pétrea, como buena parte de Anatolia, Siria o Armenia. En todos los casos se trata de territorios que formaban parte del imperio o se encontraban dentro de la órbita bizantina ${ }^{38}$. Hay igualmente otros aspectos de esta zona de la mezquita que pueden ser relacionables con Bizancio. Se ha señalado que la concepción espacial de la macsura es más propia de un recinto cristiano que de una mezquita musulmana ${ }^{39} \mathrm{y}$, en ese sentido, es posible relacionar la macsura con los espacios acotados mediante iconostasios frente a los ábsides de las iglesias bizantinas, e incluso las puertas del sabat y del tesoro con los accesos a prothésis y diakonikon ${ }^{40}$. Incluso para el espacio del lucernario podría pensarse en una posible inspiración en los nártex de las iglesias bizantinas, con la macsura y mihrab a modo de cabecera.

En cuanto a las tres bóvedas de la macsura ${ }^{41}$ es cierto que no hay muchos ejemplos bizantinos de tres cúpulas alineadas transversalmente al eje del templo, aunque existan algunos ejemplos como la iglesia de San Juan de Éfeso del siglo VI. No obstante, cabe mencionar ejemplos interesantes en las artes suntuarias como el fragmento de un cetro de marfil (886-912, Museum für Spatantik und Byzantinische Kunst, Berlín) que presenta dos escenas con composiciones equivalentes: en una el emperador León VI coronado por un ángel y acompañado por el arcángel Gabriel, y en la otra Cristo flanqueado por discípulos. En ambos casos las figuras se representan cobijadas bajo tres elementos arquitectónicos gallonados, el central con tambor y ventanas, y los laterales de menor altura. Asimismo, se ha relacionado con la apariencia de la macsura y el mihrab de Córdoba el relicario de San Anastasio (c. 970, Domkapitel, Aachen) ${ }^{42}$. Este objeto parece que fue encargado por Eustathios Maleinos, comandante de las tropas bizantinas en Antioquía, aunque hay quien opina que se inspira más en la arquitectura armenia o georgiana que en la propiamente bizantina ${ }^{43}$.

La existencia de bóvedas semejantes a las califales cordobesas, aunque más tardías, en territorios vinculados a la zona oriental del imperio bizantino es un poderoso argumento a tener en cuenta. Durante los siglos IX y X Armenia estuvo frecuentemente ligada política y culturalmente al imperio bizantino; de hecho, varios personajes destacados del imperio, incluyendo a algunos de la familia imperial, eran de ascendencia armenia. Fueron armenios, al menos en parte, los emperadores Romano I (920-944),

38 H. STIERLIN, Orient Byzantin: de Constantinople à l'Arménie et de Syrie en Ethiopie, Freiburg, 1998.

39 P. MARFIL RUIZ, op. cit., 2004, p. 93.

40 J. DODDS, Architecture and Ideology in Early Medieval Spain, Pennsylvania, 1990, pp. 99-100, e Ibídem, "La mezquita de Córdoba", Al Andalus. Las artes islámicas en España, Nueva York y Madrid, 1992, pp. 11-25. La autora sugirió que las plantas del mihrab y la macsura se inspiraron en la arquitectura altomedieval hispánica, especialmente en la mozárabe.

41 P. MARFIL, op. cit., 2004, p. 92, opina que la influencia bizantina es patente en estas cubiertas, incluso en la intención de crear espacios cubiertos con cúpulas.

42 C. ABAD CASTRO, op. cit., 2009, p. 24.

43 R. OUSTERHAUT, "Reliquary of Saint Anastasios the Persian", H.C. EVANS, y W.D. WIXOM (eds.) The Glory of Byzantium. Arts and Culture of the Middle Byzantine Era, A.D. 843-1261, Nueva York, 1997, p. 461. 
Nicéforo Focas (963-969) y Juan Tzimisces (969-976) ${ }^{44}$. Armenia disfrutó de autogobierno a partir del 885 cuando el califa abbasí y el emperador bizantino reconocen a Ashot Bagratuni como rey de Armenia, y será totalmente independiente medio siglo después. Será un período constructivo que continuará hasta la invasión selyuquí en la segunda mitad del siglo XI. Durante el siglo X Armenia fue el centro de conexión entre el imperio bizantino y el califato abbasí de Bagdad, desarrollándose una importante actividad comercial ${ }^{45}$.

Las plantas de sus basílicas tienen las mismas características que las bizantinas, y muestran las mismas coincidencias ya apuntadas en sus cabeceras con el espacio del mihrab y la macsura de la mezquita. Respecto a las relaciones en la arquitectura con el centro del imperio cabe mencionar el ejemplo del arquitecto armenio Tirdat (activo desde 973 hasta principios del siglo XI) ${ }^{46}$. Él construyó la catedral de Ani (terminada en el 1001), y en el año 989 fue llamado a Constantinopla para reparar los daños originados en la cúpula de Santa Sofía por un terremoto ${ }^{47}$. A este mismo arquitecto se le atribuyen, entre otras, la iglesia del monasterio de Haghpat ${ }^{48}$. En Armenia existen bastantes ejemplos de arquitecturas, con frecuencia gavits ${ }^{49}$, cubiertas con bóvedas nervadas que dejan espacios centrales libres ${ }^{50}$ de diseño muy próximo a las califales cordobesas (fig. 11). Aunque estos ejemplos son posteriores, autores como Baltrusaitis han defendido que los principios de estas arquitecturas fueron fijados en los siglos $\mathrm{X}$ y XI ${ }^{51}$. Puede añadirse que en la arquitectura armenia para el apeo de cúpulas se emplean trompas además de pechinas ${ }^{52}$.

Las otras bóvedas relacionables con las andalusíes, las persas selyuquíes de la mezquita de Ispahán (fig. 12), de hecho deben de estar conectadas con las armenias, y pueden mencionarse otras coincidencias de la arquitectura abbasí con aspectos de la macsura de la mezquita de Córdoba. Por una parte, la disposición simétrica con dos puertas flanqueando el mihrab tiene su antecedente en las mezquitas congregacionales de Samarra ${ }^{53}$. Por otra, en la decoración de la fachada del mihrab de la mezquita de al-Mutawakkil en Samarra se había recuperado la tradición omeya de los mosaicos dorados, y Torres Balbás y Ewert señalan la presencia de motivos decorativos emparentados con el estilo C de Samarra en los estucos de la base de las bóvedas de la macsura ${ }^{54}$.

44 H. C. EVANS, “Christian neighbours”, H.C. EVANS y W.D. WIXOM (eds.), The Glory of Byzantium, Nueva York, 1997, pp. 276 y 351; P. CHARANIS, The Armenians in the Byzantine Empire, Lisboa, 1963, pp. 23-30.

45 J. A. CELIK, The Ecclesiastical Architecture of Armenia in the Tenth and Eleventh Centuries with Special Reference to Georgia, Anatolia and Constantinople, Tesis doctoral manuscrita, Universidad de East Anglia, 1975, pp. 12 y ss.

46 P. CUNEO, Architettura Armena dal quarto al diciannovesimo secolo, tomo I, Roma, 1988, p. 62.

47 H. C. EVANS, op. cit., 1997, p. 352.

48 J. A. CELIK, op. cit., 1975, pp. 12 y ss.

49 El gavit o jamadun, una especie de porche o nártex, es una creación puramente armenia que aparece en el siglo X, Ibídem, p. 110.

50 P. CUNEO, op. cit., 1988, pp. 302 y ss., y p. 739.

51 J. BALTRUSAITIS, Le problème de l'ogive et l'Armenie , Paris, 1936, p. 35.

52 P. CUNEO, op. cit., 1988, p. 800.

53 S. CALVO CAPILLA, op.cit., 2008, p. 94.

54 Ibidem, p. 104, nota 34. 


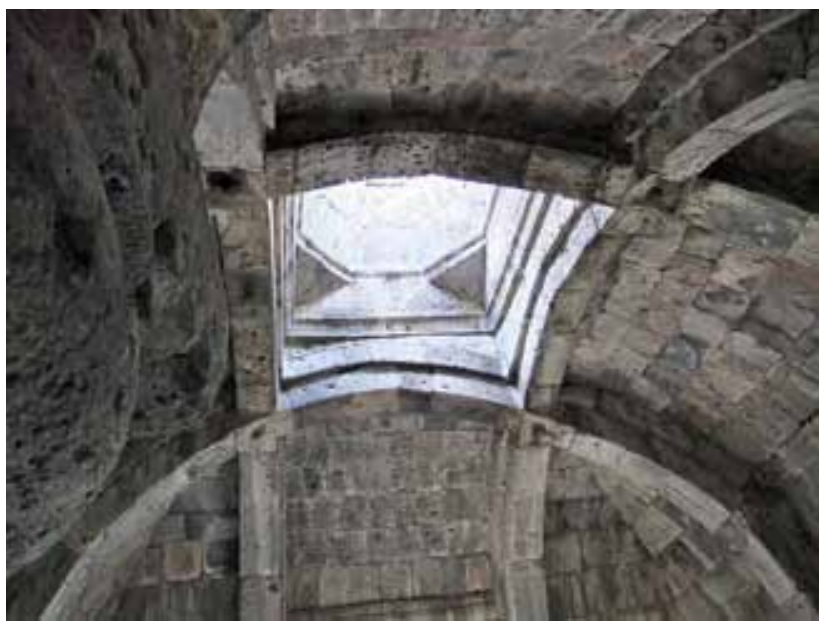

Fig. 11. Monasterio de Haghpat (Armenia): bóveda del refectorio.

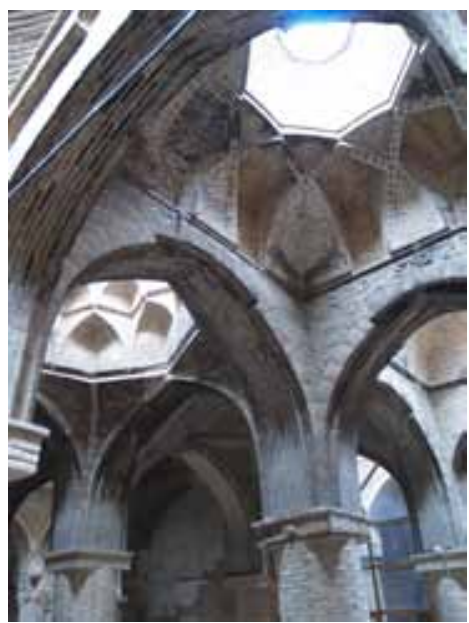

Fig. 12. Mezquita de Ispahán (Irán): bóvedas de la sala de oración.

\section{LA ARQUERÍA TRANSVERSAL}

Esta construcción clave dentro de este análisis de la génesis y desarrollo del oratorio de al-Hakam II presenta una serie de aspectos originales no explicados en relación con sus posibles modelos y orígenes.

Los dos primeros arcos que flanquean el frente de la macsura son arcos apuntados (fig. 13). No conocemos ejemplos anteriores en la arquitectura omeya de al-Andalus y son muy escasos posteriormente. Sus posibles precedentes en la arquitectura islámica fueron señalados por Torres Balbás quien, al referirse a ellos, los considera de indudable origen oriental y señala una serie de posibilidades ${ }^{55}$. Se basa esencialmente en ejemplos indicados por Creswell ${ }^{56}$, que se remontan a la arquitectura omeya de Oriente, y entre los edificios mencionados se encuentran algunos palacios del desierto como Mshatta. Fue arco característico de la arquitectura abbasí, y así lo hemos visto en Samarra, y lo es también de su expansión y desarrollo, en este caso hacia el Occidente del Islam, por ejemplo en Egipto, en edificios como las mezquitas de Ibn Tulun y al-Hakim en el Cairo, o en el nilómetro de la isla de Roda. Por su parte, en la arquitectura bizantina se conoció el arco apuntado y se empleó en cisternas, como en la cisterna Binbirdirek o de las Mil y Una Columnas de Estambul ${ }^{57}$, o la iglesia de los Santos Sergio y Baco. En Armenia se emplean profusamente entre mediados del

55 L. TORRES BALBÁS, op. cit., 1965, p. 488. Asimismo, indica que el arco agudo sirvió de traza auxiliar para la de los lobulados.

56 K.A.C. CRESWELL, Early Muslim Architecture, vol. 1, Ummayads, A.D. 622-750, Oxford, 1969.

57 A. VAN MILLIGAN, Byzantine Churches in Constantinople, Londres, 1912, p. 15. 


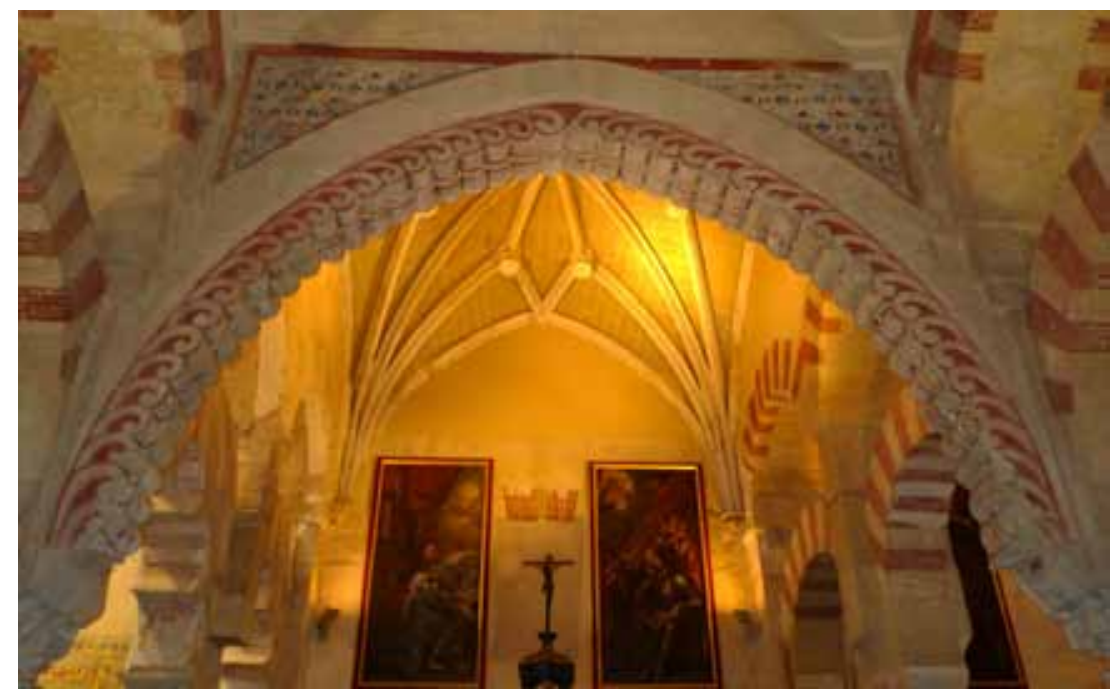

Fig. 13. Ampliación de Al-Hakam II: arco apuntado de la arquería transversal.

siglo $\mathrm{X}$ y mediados del siglo $\mathrm{XI}^{58}$, con ejemplos tan significativos como Santa Cruz de Achtamar (915-921) y la catedral de Ani (980-1001).

El intradós de todos los arcos de esta arquería transversal es almohadillado, en una especie de sucesión de rizos a lo largo de todo su perfil. Es difícil encontrar ejemplos propiamente arquitectónicos de este tipo de decoración en arcos hasta la arquitectura fatimí egipcia y suelen ser más tardíos, como en la Bab al-Futuh de El Cairo (segunda mitad del XI) ${ }^{59}$, donde también se emplea el arco apuntado. En las artes suntuarias bizantinas de los siglos VI al XI, particularmente en los marfiles, se representan arcos con elementos decorativos en el intradós que podrían tener alguna relación como referencia. También en el monasterio armenio de Kecaris parece haber un gran arco ciego con decoración almohadillada aunque, aparentemente corresponde ya al siglo XIII ${ }^{60}$.

Todos los arcos de la arquería transversal cuentan con albanegas caladas. Puede haber sido una solución para aligerar el peso de la estructura del arco en una zona en la que no es necesario, e incluso puede ser contraproducente que tengan esa masa, puesto que la función de descarga del peso de las bóvedas la van haciendo los propios arcos y, en todo caso, la línea superior que conecta sus claves con la parte superior de los soportes. Estrictamente la misma idea no la he encontrado en ningún sitio, tal vez porque se trate realmente de una novedad decorativa forzada por la razón constructiva antes señalada. Sin embargo, existen decoraciones que sugieren arcos calados,

58 J.A. CELIK, op. cit., 1975, p. 54.

59 L. TORRES BALBÁS, op. cit., p. 490: declara no conocer ningún ejemplo anterior de arco con este tipo de reborde en su intradós.

60 P. CUNEO, op. cit., 1988, p. 156. 
pero a todo lo largo de los mismos, no solo en las albanegas, en bastantes marfiles bizantinos de los siglos X y XI. Por lo que respecta a los diseños geométricos que muestran estos diseños calados, pueden encontrarse en obras islámicas de diferentes períodos $y$, desde luego, son del tipo que existen en el arte del Califato cordobés ${ }^{61}$.

En conclusión, puede afirmarse que, de muchas maneras, la ampliación de alHakam II en la mezquita de Córdoba es indiscutible ejemplo de la fusión de influencias y referencias artísticas propias del arte del Califato, con un importante componente relacionado con el arte bizantino.

\section{LA DIFUSIÓN}

Las bóvedas de crucería califal son igualmente un perfecto ejemplo de la difusión de modelos artísticos procedentes del arte califal cordobés. A partir de estos primeros ejemplos conservados en el oratorio de al-Hakam II, puede comprobarse cómo los diseños de las mismas se extienden en la arquitectura hispanomusulmana posterior, pasan a obras mudéjares y a la arquitectura cristiana medieval, no solo en la Península Ibérica, sino incluso en territorios ultrapirenaicos. Sus diseños geométricos no solo siguen los tres modelos existentes en la mezquita de Córdoba, sino que presentan bastantes subtipos. Ello también indica que las variantes de estas bóvedas creadas en la arquitectura califal cordobesa debieron ser más. El mejor testimonio de ello son las nueve pequeñas bóvedas existentes en la mezquita toledana de Bab al-Mardum, construida en 999-1000.

Los modelos que con más frecuencia se encuentran en la arquitectura románica y en la gótica son dos, si bien es importante señalar que se trata, en la práctica totalidad de los casos, exclusivamente de una imitación del diseño y no de la técnica constructiva. El primero de estos dos modelos es el derivado de las bóvedas laterales de la macsura de la mezquita de Córdoba, un diseño de estrella de ocho puntas basado en el cruce de cuatro pares de nervios. Este es el que aparece, por ejemplo, en iglesias románicas españolas como la de San Miguel de Almazán (Soria) y la del Santo Sepulcro de Torres del Río (Navarra) (fig. 14), así como en algunas en Francia, como las de la Santa Cruz de Oloron-Sainte-Marie y la de L'Hôpital de Saint-Blaise, ambas cerca de los Pirineos. Adaptan también este diseño las bóvedas de los cruceros de varias catedrales góticas aragonesas, como las de Teruel y Tarazona y la Seo de Zaragoza. La persistencia de este modelo de diseño de bóvedas se extiende hasta la arquitectura de época moderna, como lo prueba la de la iglesia de San Lorenzo de Milán, construida en el siglo XVII por el arquitecto barroco Guarino Guarini. El otro modelo difundido en la arquitectura cristiana medieval es el resultante de una simplificación de la bóveda del lucernario en la mezquita de Córdoba. Se basa en el cruce de dos pares de nervios que dejan un espacio libre cuadrado en su centro, diseño que ya aparece en la mezquita de Bab al- Mardum. En la arquitectura románica española lo encontramos

61 B. PAVÓN, El arte hispanomusulmán en su decoración geométrica. Una teoría para un estilo, Madrid, 1975. 


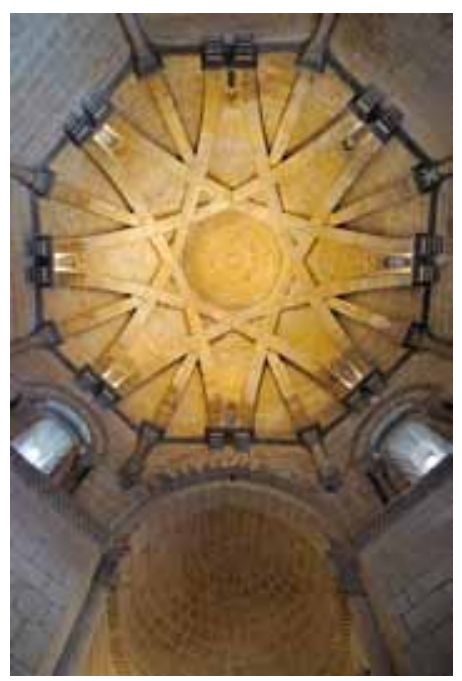

Fig. 14. Bóveda de la iglesia del Santo Sepulcro de Torres del Río (Navarra).

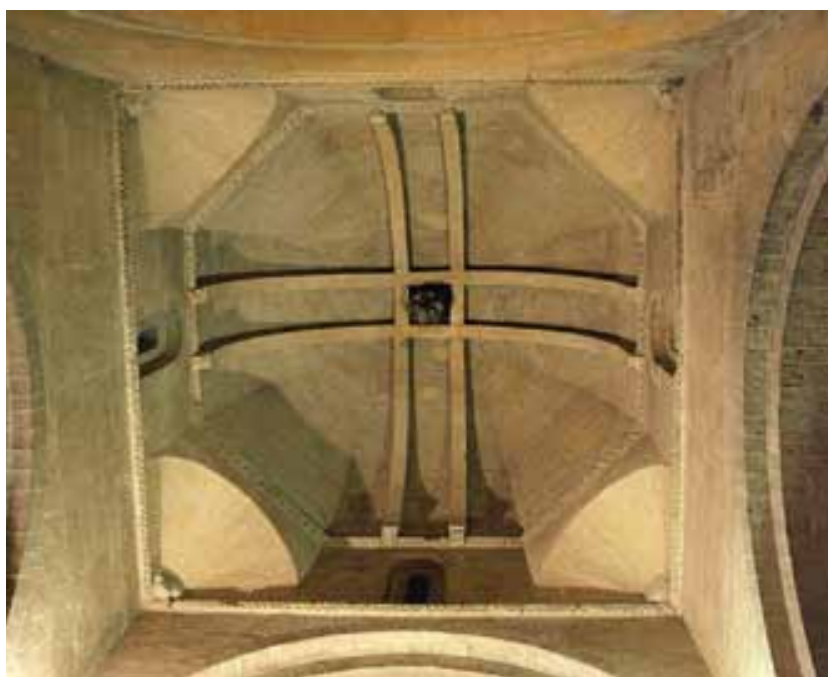

Fig. 15. Bóveda de la iglesia del Santo Sepulcro de Torres del Río (Navarra).

en la bóveda del crucero de la iglesia de San Millán (fig. 15) y en la planta superior del cuerpo central de la iglesia de la Vera Cruz, ambas en Segovia ${ }^{62}$.

Ahora bien, la bóveda derivada de las califales cordobesas que mayor interés ha despertado siempre en mí es la de la antigua cocina del priorato de la catedral de Durham en Inglaterra ${ }^{63}$ (fig 16). Esta dependencia de la catedral es una construcción del siglo XIV adosada al extremo suroeste del claustro. Fue construida por el arquitecto John Lewyn entre 1367, cuando consta que era maestro mayor de la obra, y 1374 por encargo del influyente obispo de Durham Thomas Hatfield (1362-1381) ${ }^{64}$. John Lewyn fue un destacado arquitecto del norte de Inglaterra especializado en arquitectura militar cuya carrera está documentada entre 1353 y 1398 . Se ha dicho que en la construcción de la bóveda de Durham había copiado exactamente, aunque de manera inconsciente, las formas de las bóvedas persas de ladrillo de los siglos XII y XIII ${ }^{65}$. Otros autores han señalado repetidamente su parecido con estas bóvedas persas, con las de la arquitectura armenia y, por supuesto, con las hispanomusulmanas e, incluso, que derivaba de la del Octágono de la catedral de Ely.

62 A. MOMPLET, "La presencia de modelos islámicos de abovedamientos en la arquitectura cristiana española de los siglos XI al XIII”, Entre el Califato y la Taifa. Mil años del Cristo de la Luz, Toledo, 1999, pp. 347-355.

63 Ibídem, "De Córdoba a Durham: el viaje de una arquitectura andalusí", Goya: Revista de Arte (en prensa).

64 M.J.B. HISLOP, "John Lewyn of Durham: a North Country Master Mason of the 14th Century", Journal of the British Archaeological Association, 151 (1988), p. 171. Este dato consta en: J. J. FOWLER (ed.), Durham Account Rolls, II, Surtees Society 100, 1898.

65 J. HARVEY, Gothic England 1300-1550, London, 1947, p. 55. 


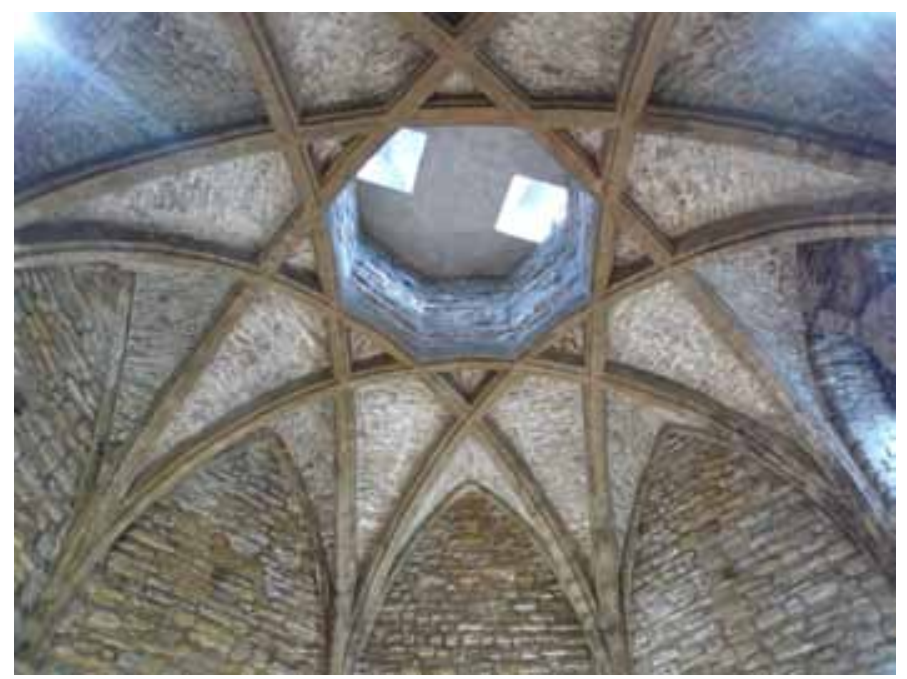

Fig. 16. Catedral de Durham (Inglaterra): bóveda de la cocina.

Entre los clientes de John Lewyn cabe destacar a John de Gaunt, duque de Lancaster, para el que construyó en 1380 un recinto defensivo alrededor de la gran torre del castillo de Dunstanburgh ${ }^{66}$. John de Gaunt (1340-1399) era hijo del rey Eduardo III de Inglaterra, cuyo primogénito era Eduardo, príncipe de Gales, conocido como el Príncipe Negro (1330-1376). En 1362 Eduardo III de Inglaterra hizo un tratado con Pedro I de Castilla y le ofreció ayuda contra su hermanastro Enrique de Trastámara. Cuando Pedro fue depuesto por Enrique en 1366, el Príncipe Negro aprovechó la ocasión para recuperar su reputación militar al mando de un ejército que se unirá al rey castellano en Gascuña para entrar en la Península a combatir a su hermanastro. Triunfaron en la guerra civil reponiendo a Pedro en el trono tras la victoria en la batalla de Nájera el 3 de abril de $1367^{67}$. El duque de Lancaster fue el segundo en el mando, tras su hermano mayor, en esta campaña en la que varios miles de ingleses, se calcula que hasta diez mil, acudieron para apoyar a Pedro I ${ }^{68}$.

66 M. J. B. HISLOP, op. cit., 1988, p. 171; este dato procede de E. C. LODGE y R. SOMMERVILLE (eds.), John of Gaunt's Register, 1379-1383, Camden Society, $3^{\text {rd }}$ se., 56 y 57, (1937), I, pp. 135-136, y II, p. 291; el contrato se encuentra publicado en L. F. SALZMAN, Building in England Down to 1540, Oxford, 1952; y en W. D. SIMPSON, "Further Notes on Dunstanburgh Castle", Archaelogia Aeliana, $4^{\text {th }}$ ser., 27 (1949), pp. 2122; la obra de John Lewyn en el castillo de Dunstanburgh se estudia asimismo en: A. OSWALD, J. ASHBEE, K. PORTEROUS y J. HUNTLEY, Dunstanburgh Castle, Northumberland. Archaeological, Architectural and Historical Investigations, Research Department Report Series, $\mathrm{n}^{\circ}$ 26, English Heritage, 2006, pp. 47 y ss.

67 W. M. ORMROD, The Reign of Edward III. Crown and Political Society in England 1327-1377, Yale, 1990 , p. 28.

68 L. V. DÍAZ MARTÍN, Pedro I el Cruel (1350-1369), Burgos, 2007, pp. 247-259: "La invasión inglesa", "Nájera" y "Los ingleses en Castilla"; P. E. RUSSELL, The English Intervention in Spain and Portugal in the Time of Edward III and Richard II, Oxford, 1955, p. 80. 
Durante esta campaña el ejército anglo-castellano estuvo acampado en las cercanías de las iglesias francesas de la Aquitania antes mencionadas que incluyen bóvedas de tipo califal, y ya en Navarra pasó entre Viana y Logroño ${ }^{69}$, donde se encuentra la iglesia del Santo Sepulcro de Torres del Río que cuenta con otra bóveda especialmente espectacular, y cuya traza es también similar a la construida por John Lewyn en Durham. Además, tras la batalla de Nájera el Príncipe Negro se alojó en el monasterio de Las Huelgas en Burgos ${ }^{70}$, en donde la capilla de la Asunción se cubre asimismo con otra bóveda de tipo califal.

Si consideramos que en esta época un ejército de estas características contaba necesariamente con un cuerpo de especialistas en arquitectura militar, esenciales para disponer y construir sistemas y elementos de ataque y defensa ${ }^{71}$, es razonable suponer que John Lewyn pudo haber sido integrante de ese ejército con este tipo de función.

En 1369 Enrique matará al rey Pedro I sucediéndole definitivamente en el trono castellano. Poco después, en septiembre de 1371, el duque de Lancaster se casó con Constanza, hija mayor del rey fallecido. En consecuencia, pasó a ser pretendiente al trono de Castilla frente a los Trastámara. Apoyándose en los derechos de Constanza, a partir de 1372 asumió oficialmente el título de rey de Castilla y León e incluyó en su emblema heráldico las armas de Castilla y León. Precisamente, en el contrato fechado en 1380 con John Lewyn para la obra en su castillo de Dunstanburgh figura utilizando esos títulos (Juan, rey de Castilla y León y duque de Lancaster) ${ }^{72}$. Durante dieciséis años (1371-1387) conservó sus aspiraciones a la corona, realizando todo tipo de movimientos para obtenerla, y mantuvo en Inglaterra una corte, centro de "legitimismo" castellano, en la que durante años hubo un importante grupo de caballeros y damas castellanos incluyendo numerosos leales al difunto Pedro I.

En consecuencia, se abre una segunda hipótesis para explicar el conocimiento por parte de John Lewyn de soluciones arquitectónicas procedentes de la Península Ibérica. Lógicamente, conectados con estos nobles y sus séquitos, hubo otros castellanos de menor rango y diversas ocupaciones relacionados con la corte de Lancaster ${ }^{73}$. No sería de extrañar que el arquitecto inglés pudiese haber conocido, incluso colaborado, con algún alarife de origen castellano que hubiese llegado a Inglaterra en estas circunstancias.

Estas son las razones que, a través del conocimiento del entorno y la obra de John Lewyn, permiten pensar que debió inspirarse directa o indirectamente, en modelos de origen andalusí para la bóveda que construyó en la cocina de la catedral de Durham. Sin embargo, existe otra obra de Lewyn para ratificar esta hipótesis en el castillo de Raby.

69 Ibídem, pp. 82 y 92.

70 L. V. DÍAZ MARTÍN, op. cit., 2007, p. 255.

71 P. CONTAMINE, La guerra en la Edad Media, Barcelona, 1984, p. 132: señala la existencia en los ejércitos de la época de personal técnico "maestros en ingenios" e "ingenieros"; ver también J. GARDELLES, Les chateaux du Moyen Age dans la France du Sud-Ouest. La Gascogne anglaise de 1216 à 1327, GinebraParis, 1972, y R. RITTER, L'architecture militaire médiévale, Paris, 1974.

72 M. J. B. HISLOP, op. cit., 1988, p. 77; P. E. RUSSELL, op. cit., 1955, p. 175.

73 Ibídem, pp. 173-185. 


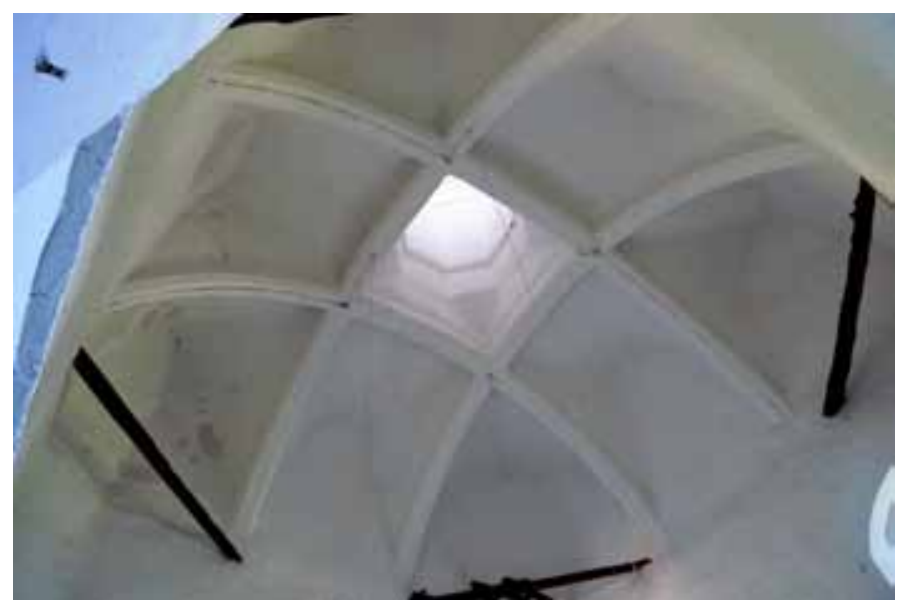

Fig. 17. Castillo de Raby (Inglaterra): bóveda de la cocina.

Este castillo está situado en el condado de Durham a unos treinta kilómetros al suroeste de la ciudad episcopal. Se trata de uno de los castillos medievales mejor conservados del norte de Inglaterra ${ }^{74}$, y fue la residencia de la familia Neville hasta 1569. Lo fundamental del castillo fue construido en tiempos de Ralph, cuarto barón Neville (1331-1367) y John, quinto barón Neville (1367-1388), ambos directamente vinculados al duque de Lancaster y a sus campañas políticas y militares relacionadas con Castilla. Se considera que John Lewyn fue el arquitecto responsable de las obras del castillo en esta época ${ }^{75}$.

La cocina del castillo de Raby es uno de los espacios conservados originales del siglo XIV, y es una formidable estancia de planta cuadrada con una superficie de unos ochenta metros cuadrados. Se cubre por una bóveda cuya linterna central tenía originalmente unos veintiún metros de altura y fue sobreelevada ocho pies en el siglo XVIII. Es una bóveda del tipo de crucería califal compuesta por cuatro nervios dispuestos en dos pares paralelos que, al cruzarse perpendicularmente, dejan un espacio central cuadrado en donde se alza la susodicha linterna octogonal apoyada en trompas

74 Quiero expresar mi agradecimiento a la conservadora del castillo, Clare Owen, a su propietario Harry John Neville Vane, onceavo Lord Barnard, y al personal del mismo, por la amable colaboración que me prestaron durante mi visita para poder recoger información para mi investigación.

75 M. J. B. HISLOP, John Lewyn of Durham. A Medieval Mason in Practice, Oxford, 2007, pp. 8-10 y 6367. Este libro amplía y completa el artículo publicado en 1988 por el mismo autor. Además de esta publicación, que es la mas extensa y documentada sobre John Lewyn y sobre su participación en la construcción de Raby, sobre este edificio y su historia también pueden consultarse: M. HISLOP., "The Castle of Ralph Fourth Baron Neville at Raby", Archaeologia Aeliana, ser. 5, 20 (1992), pp. 91-97; A. ROWAN, "Raby Castle, Co. Durham", Country Life, julio 10 y 17 de 1970, y enero 1, 8 y 22 de 1969; A. ROWAN, "Gothic Restoration at Raby Castle", Architectural History, 20 (1972), pp. 21-50; J. F. HODGSON, "Raby”, Journal of the British Archaeological Association, 43 (1887), pp. 307-27; H. J. NEVILLE VANE, Raby Castle. The Home of Lord Barnard, Londres, 2008; O. S. SCOTT, Guide Book, 1936 (revisado por HARRISON, 1953); y R. INNESSMITH, Raby Castle, Norfolk, 2010. 
(fig. 17). El diseño de bóveda se inspira en los modelos andalusíes ya mencionados, y cuyos ejemplos más antiguos conservados se encuentran en la mezquita toledana de Bab al-Mardum (999-1000), aunque su traza parta de la de la bóveda del lucernario (961-971) de la mezquita de Córdoba. Es el tipo de bóveda que se transmitirá a la arquitectura cristiana medieval hispana con ejemplos como los ya señalados de las iglesias segovianas de San Millán y de la Veracruz en Segovia.

La espectacular cocina del castillo de Raby confirma que John Lewyn debió encontrar su inspiración para la de la cocina de la catedral de Durham en modelos andalusíes, bien vistos por él directamente o aprendidos de manera indirecta a través de los contactos que pudo establecer relacionados con la corte de John de Gaunt, duque de Lancaster y rey de Castilla y León. 